\title{
AS DISCIPLINAS CIENTÍFICAS DO ENSINO BÁSICO NA LEGISLAC̣ÃO EDUCACIONAL BRASILEIRA NOS ANOS DE 1960 E 1970
}

\author{
MARIA NEUZA ALMEIDA QUEIROZ ${ }^{*}$ \\ https://orcid.org/0000-0002-5076-2260 \\ YASSUKO HOUSOME ${ }^{* *}$ \\ https://orcid.org/0000-0002-7295-436X
}

RESUMO: O presente estudo revela o espaço reservado ao ensino científico, pela análise da presença das disciplinas da Ciências da Natureza (Ciências, Física, Química e Biologia) nos currículos do ensino secundário na vigência da Lei 4.024/1961 (LDB/1961) e no $2^{\circ}$ Grau na reforma de 1971 (Lei $5.692 / 1971)$. Tais leis vigoraram em um momento histórico de grandes inovações no ensino de Ciências em diversas partes do mundo, bem como de influências e intervenções externas no sistema educacional brasileiro. Apresentamos a análise de documentos que nortearam as organizações curriculares a nível nacional, bem como de alguns Estados da federação brasileira nesse contexto de mudanças. O discurso das leis indica que essas não foram efetivadas por meio das instruções e normas educacionais mais específicas, pois o número de aulas reservado às disciplinas científicas bem como a presença dessas nas séries não tiveram aumento em relação à organização curricular da reforma anterior (Reforma Capanema).

Palavras chave: Legislação educacional. Ensino de Ciências. Currículo.

\section{LAS ASIGNATURAS CIENTÍFICAS DE ENSEÑANZA BÁSICA EL LA LEGISLACIÓN EDUCACIONAL BRASILEÑA EN LAS DÉCADAS DE 1960 Y 1970}

RESUMEN: La presente investigación revela el espacio reservado a la enseñanza científica, por el análisis de la presencia de asignaturas de las Ciencias de la Naturaleza (las Ciencias, la Física, la Química y la Biología) en los currículos de la enseñanza secundaria en la vigencia de la Ley 4.024/1961 (LDB/1961) y en el segundo grado en la reforma de 1971 (Ley 5.692/1971). Tales leyes se aplicaron en un momento
"Doutora em Ensino de Ciências pela Universidade de São Paulo. Professora de Física no Ensino Médio Integrado ao Ensino Técnico e no Curso de Engenharia Civil do IFNMG - Campus Pirapora - MG. E-mail:< neuza.queiroz@ifnmg.edu.br > .

“*Doutora em Educação pela Universidade de São Paulo. Prof ${ }^{a}$ Aposentada pela Universidade de São Paulo. Orientadora no Programa de Pós-Graduação Interunidades em Ensino de Ciências USP - SP. E-mail:<yhosoume@if.usp.br>.

\footnotetext{
' Universidade de São Paulo, São Paulo, SP - Brasil.
} 
histórico de grandes innovaciones en la enseñanza de las Ciencias en diversas partes del mundo, así como de influencias e intervenciones externas en el sistema educacional brasileño. Presentamos el análisis de documentos de guiaron las organizaciones curriculares a nivel nacional, bien como de algunos estados de la federación brasileña en ese contexto de cambios. El discurso de las leyes indica que ellas no fueron efectuadas por medio de las instrucciones y normas educacionales más específicas, pues la cantidad de clases reservadas a las asignaturas científicas bien como su presencia en los años escolares no aumentaron en relación a la organización curricular de la reforma anterior (Reforma Capanema).

Palabras clave: Legislación educacional. Enseñanza de las Ciencias. Currículo.

\section{THE SCIENTIFIC DISCIPLINES OF BASIC EDUCATION IN BRAZILIAN EDUCATIONAL LEGISLATION IN THE YEARS OF 1960 AND 1970}

ABSTRACT: The present study reveals the space reserved for scientific education, through analysis of the Life Sciences disciplines (Sciences, Physics, Chemistry and Biology) of secondary education in enforcement of the Law 4.024 / 1961 (LDB / 1961) and the 1971 reform (Law 5.692 / 1971). These laws took place in a historical moment of great innovations in the teaching of Sciences in diverse parts of the world, as well as of influences and external interventions in the Brazilian educational system. This study presents an analysis of documents that guided national curricular organizations, as well as some states of the Brazilian federation in this changing context. The discourse of the laws indicates that these were not effected through the more specific instructions and educational norms, since the number of classes reserved for the scientific disciplines, as well as their presence in the school years, did not increase in relation to the curricular organization of the previous reform (Reformation Capanema)

Keywords: Educational Law. Science Teaching. Curriculum. 


\section{INTRODUÇÃO}

A análise da dinâmica política, econômica e social que permeia a definição dos princípios norteadores do processo de escolarização nas diversas sociedades tem como concordância a ideia de que as reformas educacionais giram em torno de conflitos ideológicos, jogo de interesses e disputa de poder. Esta parece ser uma visão genérica entre vários teóricos críticos do currículo, como exemplo, Goodson (1995, 1999), Apple (1997) e Sacristán (2000).

As reformas educacionais trazem a promessa da inovação, e quanto aos currículos, esses se desenvolvem "sob a forma de diferentes padrões curriculares, comprometidos com particulares concepções de educação”. (FERRETTTI, 1980, p. 59). Cabe examinar se tais desenvolvimentos se traduzem de fato em modificações (significativas ou substanciais?), e em que demandas se pautam. Conforme alerta Werebe (1980),

É preciso distinguir preliminarmente o pano ideal do real, quando se analisa a legislação escolar. Mesmo no caso dos países mais avançados, esta legislação contém certos ideais elevados, ou intenções verdadeiramente democráticas que não se efetivam na prática. (WEREBE, 1980, p. 253).

Nesse mesmo sentido, Goodson (1999) contrapõe o paradigma das inovações e progressos supostamente postos a partir de reformas curriculares, especialmente àqueles oriundos dos "movimentos mundiais". (GOODSON, 1999, p. 109). O autor defende uma análise circunstancial para a compreensão dessas supostas mudanças, de modo a permitir um posicionamento real a respeito de suas nuances progressivas ou regressivas. Além disso, ele sugere uma análise crítica pautada em estudos históricos de alcance maior, de modo a perceber as mudanças em sua dinâmica contextual.

A advertência de Goodson vem no sentido de alertar para a percepção das inovações curriculares influenciadas por padrões e causas de um contexto passado, bem como para a necessidade de analisar as consequências destas em recortes históricos de maior extensão, pós-alterações, pois, segundo esse autor, embora a educação seja sujeita a processos de reestruturação, não há garantia de que nos intramuros da escola tais processos surtam algum efeito. (GOODSON, 1999). Nessa mesma linha, Ball (2001, p. 105) defende que "os processos de implementação das reformas têm que ser analisados ao longo do tempo e em termos da sua relação com elementos variados”. As reformas educacionais não ocorrem de forma harmônica: embates, acomodações, reações (antagônicas ou favoráveis) são movimentos intrínsecos a qualquer reforma no âmbito dos sistemas educacionais. Conforme ressalta Goodson (1999, p. 113), os estudos sobre as mudanças educacionais devem "analisar as 'estruturas da oportunidade', onde sua mudança apresentará o efeito.” A ausência desse exame pode levar à exaltação de reformas (ou de algum ponto específico delas) que não apresentam de fato as modificações demandadas, e até mesmo prometidas no texto da lei.

De um modo geral, o foco das mudanças educacionais é a organização curricular com suas matérias ou disciplinas e orientações específicas. "A disciplina 
é um dos inúmeros prismas através dos quais podemos visualizar a estrutura que envolve a educação estatal". (GOODSON, 1999, p. 115).

A proposta deste artigo foi de analisar um ponto específico das reformas curriculares no Brasil oriundas da Primeira Lei de Diretrizes e Bases da Educação Brasileira (LDBN/1961) e em particular a Lei 5692/1971, que tornou o ensino médio em profissionalizante. Focamos nas mudanças para o ensino da Ciências da Natureza, composta das disciplinas Ciências, Física, Química e Biologia, durante a implementação de tais reformas. Assim, este trabalho centrou-se nas mudanças gerais que orientaram o ensino médio da educação básica, nos anos de 1960 e 1970, nos termos das legislações, confrontando as premissas dessas leis com as regulamentações que definiram o espaço concedido às disciplinas que compunham a área Ciências da Natureza. Buscamos identificar consistências internas na perspectiva das "estruturas da oportunidade", que permitiram ou não as modificações na direção proposta nas leis maiores que balizaram as reformas educacionais do período analisado.

No plano metodológico, trata-se de uma pesquisa histórico-documental, que traz como fontes principais a Lei de Diretrizes e Bases da Educação (Lei n ${ }^{\circ}$ 4.024/1961) e a Reforma do ensino de $1^{\circ}$ e $2^{\circ}$ graus de 1971 (Lei no 5.692/1971) com suas normas regulamentadoras (Indicações, Pareceres, Resoluções, Leis estaduais, Atos, etc.), além de textos de diversos autores que têm como abordagem principal a história do currículo escolar no Brasil abrangendo nosso período de análise, dos quais focalizamos no que trata do ensino da Ciências da Natureza.

Buscamos as legislações e outros documentos pertinentes ao currículo da escola secundária brasileira, em coletâneas de leis, pareceres, resoluções, etc., em sítios oficiais do governo e em outros que alojam documentos históricos. Pesquisamos ainda trabalhos que discutem os textos de tais legislações, bem como a implementação das mesmas, como exemplo, Cunha e Abreu (1965), Nagle (1973), Fontoura [1979?] e Romanelli (1985). Parte dos documentos oficiais da década de 1960 foram cedidos, em cópias digitalizadas, pelo Conselho Nacional de Educação. Localizamos ainda documentos de reforma de currículos de alguns Estados da federação, tais como: São Paulo (1963, 1969, 1978); Estado de Minas Gerais (1976) e Estado do Paraná (1962, 1972).

Esses documentos foram analisados com recorte nas disciplinas que compõem a Ciências da Natureza com intuito de estabelecer temas que poderiam compor as categorias de análise. Pela própria natureza do material de análise e nos pautando em trabalhos de vários autores que afirmam que estas disciplinas tiveram aumento significativo de horas/aulas após a reforma educacional de 1961, escolhemos como dimensões de análise nesta pesquisa a presença das disciplinas e o quantitativo de horas/aulas para as mesmas nas composições dos currículos das séries do ensino médio (Ginasial/Colegial/2 ${ }^{\circ} \mathrm{Grau}$ ) organizados nos termos das reformas de 1961 e 1971 e seus regulamentos.

\section{CONTEXTO HISTÓRICO}

As transformações políticas, econômicas e sociais vivenciadas no Brasil em meados do século XX demandaram uma escola capaz de atender a uma quantidade 
maior de cidadãos, "forçando" tentativas para a adoção de uma educação escolar mais democrática, uma vez que, até então, frequentar escola era um privilégio bastante restrito à elite. Além disso, o contexto exigiu uma formação escolar mais ampla, que permitisse não somente a continuação em estudos superiores, mas também uma preparação para a vida social, especialmente para atender a um mercado produtivo mais evoluído tecnologicamente.

O cenário político-econômico mundial vivia o delicado momento de transição do Pós-Guerra para a bipolarização mundial nos contextos sociopolítico e econômico, a batalha política e ideológica denominada Guerra Fria. O Brasil vivia o auge do Movimento Populista, quando ocorre o retorno de Getúlio Vargas ao poder em 1951, e desta vez pelo voto direto, depois de já ter protagonizado um marcante período (1930-1945) de governo autocrata. Esse presidente assumiu mais uma vez o caráter desenvolvimentista nacionalista, dando continuidade à política de seu governo anterior (ROMANELLI, 1985). Vargas governou até 1954, quando interrompeu seu mandato, em 24 de agosto de 1954, de forma trágica com o suicídio que marcou a história política do país (ROMANELLI, 1985).

De 1954 a 1956, o país passou por três governos até o início do governo de Juscelino Kubitschek (JK), em 1956, também caracterizado por uma ideologia política desenvolvimentista. Nesse período, acentuou-se a implantação da indústria pesada no Brasil, impulsionando ainda mais o desenvolvimento industrial. Embora mantendo o modelo político do populismo, no governo de JK "abrem-se as portas da economia nacional ao capital estrangeiro" (ROMANELLI, 1985, p. 83).

Nesse ínterim, segundo Souza (2008), discutiu-se na Câmara dos Deputados, a possibilidade de uma nova Lei Orgânica do Ensino Secundário. ${ }^{1}$ Conforme essa autora, debates se acirraram sobre a inclusão ou exclusão de disciplinas no currículo, bem como novos objetivos para uma Educação com viés mais prático voltado para o mercado de trabalho. Ressalte-se que, nessa época, um anteprojeto de LDB já hibernava no congresso desde 1948. E é também neste contexto que se acendeu intensamente o debate sobre tal anteprojeto de lei.

A primeira Lei de Diretrizes e Bases da Educação brasileira (Lei N ${ }^{o}$ 4.024/1961 de 20 de Dezembro de 1961) é sancionada em um ambiente político conturbado, logo após a assunção de João Goulart como presidente da república em setembro de 1961, após uma intensa crise gerada pela renúncia do titular da chapa (Jânio Quadros) com sete meses de mandato, ocasionando um período de Governo provisório e de lutas políticas com a oposição dos militares. João Goulart governa até 31 de março de 1964, quando é deposto por um Golpe Militar.

A LDB/1961 é considerada a mais importante dentre as impactantes reformas do sistema educacional brasileiro ocorridas ao longo do século XX. Isso se deve, principalmente, pelo fato de pela primeira vez no país uma única lei tratar de todos os níveis e ramos do ensino. Além disso, esse documento traz o diferencial de ter descentralizado alguns princípios de organização do currículo escolar, concedendo aos Estados da federação e suas escolas uma moderada, porém importante, flexibilidade para definir currículos mais ajustados às peculiaridades regionais.

Antes da LDB/1961, o sistema educacional brasileiro era regido pelos Decretos-Leis da Reforma Capanema, iniciada em 1942, que contemplava uma organização curricular rígida, fechada em sua totalidade, incluindo os currículos 
mínimos na forma de programas de disciplinas determinados pelo poder público central, para todas as escolas do país. O ensino secundário, organizado com base no Decreto-Lei No 4.244/1942, se estruturava em dois ciclos. O primeiro, Ginasial, trazia a mesma denominação da reforma anterior (a de Francisco Campos/1930), porém com quatro séries. O segundo ciclo era subdividido em dois cursos: clássico e científico, com três séries cada um. No currículo do ensino secundário havia um predomínio de disciplinas de humanidades, evidenciando a ênfase humanística. Os cursos do segundo ciclo não tinham caráter de especialização, e ambos permitiam o acesso ao ensino superior. O ensino técnico (Industrial e Comercial) e o Ensino Normal, organizados por decretos distintos no período de 1942 a 1946, também eram estruturados em dois ciclos. Recebiam as denominações de ramo do ensino de grau secundário (Ensino Industrial) e ramo do ensino de segundo grau (Ensino Normal, Ensino Comercial e Ensino Agrícola). (BRASIL, 1942, 1943, 1946). Ao que parece, tais denominações eram equivalentes e ambas remetiam ao nível do ensino secundário, embora com critérios de validação diferenciados para prosseguimento nos estudos superiores.Com a LDB/1961, o ensino médio ${ }^{2}$ (em prosseguimento ao ensino primário) não sofreu significativas alterações em relação à legislação anterior. Permaneceu subdividido em dois ciclos: o Ginasial de 4 anos e o Colegial de 3 anos, abrangendo, entre outros, os cursos secundários - técnicos (industrial, agrícola e comercial) - e de formação de professores para o ensino primário e pré-primário (escolas Normais de grau ginasial e de grau colegial). (BRASIL, 1961).

A LDB/1961 definiu que competia ao Conselho Federal de Educação (CFE) definir as "disciplinas e práticas educativas" obrigatórias e optativas para compor o currículo: "indicar, para todos os sistemas de ensino médio, até cinco disciplinas obrigatórias, cabendo aos conselhos estaduais de educação completar o seu número e relacionar as de caráter optativo que podem ser adotadas pelos estabelecimentos de ensino". (BRASIL, 1961, Art. 35, \ $1^{\circ}$ ). Competia ainda ao CFE definir a amplitude e o desenvolvimento dos programas de ensino destes componentes do currículo, em cada ciclo (BRASIL, 1961, Art. 35, \ $2^{\circ}$ ); determinação esta, abnegada pelo CFE com o intuito de promover a inovação em relação à legislação anterior. É o que justifica o CFE, dez anos depois, ao emitir instruções gerais nos termos da reforma de 1971: "Não fora a maneira flexível como exerceu este Conselho a atribuição que lhe era cometida e, decerto, nenhum progresso teria havido então sobre o regime de 1942”. (BRASIL, 1971b, Documenta no 132, p. 182).

A concepção de currículo trazida na LDB/1961 teve sentido de "conjunto de todas as atividades exercitadas e vividas pelo aluno sob a direção da escola e no sentido dos objetivos por ela visados. Assim, abrange disciplinas, práticas educativas, formação moral e cívica, atividades complementares e orientação educativa e vocacional". (BRASIL, 1969, p. 17).

Em atendimento à Lei, o CFE publicou, em 24 de abril de 1962, a Indicação s/n., contendo orientações para a organização dos quadros curriculares do ensino secundário ginasial e colegial. Para os cursos técnicos e os de formação de professores pré-primário e primário, os currículos deveriam seguir, além das diretrizes da LDB, as instruções e leis especiais atinentes a cada modalidade de curso. (BRASIL, 
1962a, Art. $7^{\circ}$, p. 4557). Tal indicação trazia a lista de disciplinas obrigatórias para todos os sistemas do ensino médio secundário, bem como a lista de disciplinas complementares e optativas para o sistema federal de ensino, conforme a seguir:

- Disciplinas obrigatórias para o Ginasial e Colegial: Português (sete séries); História (seis séries); Geografia (cinco séries); Matemática (seis séries); Ciências (sob a forma de iniciação à Ciência, 2 séries, sob a forma de Ciências Físicas e Biológicas, 4 séries). O número de séries indicadas constitui o máximo, conforme Parágrafo único do Art. $1^{\circ}$.

- Disciplinas complementares do sistema federal para o Ginasial e Colegial (Apenas uma das opções apresentadas): Desenho e Organização Social e Política Brasileira; Desenho e uma língua estrangeira moderna; Uma língua clássica e uma língua estrangeira moderna; Ou duas línguas estrangeiras modernas, em ambos os ciclos; Uma língua estrangeira moderna e filosofia (no $2^{\circ}$ ciclo).

- Disciplinas de escolha pelos estabelecimentos de ensino (apenas 2 optativas das opções apresentadas, sendo 1 por série):

- Ginasial - Línguas estrangeiras modernas; Música (canto orfeônico); Artes industriais; Técnicas comerciais; Técnicas agrícolas.

- Colegial - Línguas estrangeiras modernas; Grego; Desenho; Mineralogia e geologia; Estudos sociais; Psicologia; Lógica; Literatura; Introdução às artes; Direito usual; Elementos de economia; Noções de contabilidade; Noções de biblioteconomia; Puericultura; Higiene e dietética

- Práticas Educativas para o Ginasial e Colegial (Educação Física + 1 optativa pela escola): Educação cívica; Educação artística; Educação doméstica; Artes femininas; Artes industriais; Outras indicadas pelas escolas. Nota-se que, as disciplinas Português, Matemática e História são previstas para todas as seis séries abrangidas pelas determinações gerais da Indicação, configurando o núcleo comum. Tem-se ainda o diferencial na nomenclatura da disciplina Ciências, que passou a ser Ciências Físicas e Biológicas a partir da $4^{\mathrm{a}}$ série, podendo assumir essa forma integrada também no Colegial, dependendo da opção de organização curricular adotada. Cabe ressaltar que, na sistemática anterior (Reforma Capanema), para o Colegial, as disciplinas científicas eram apresentadas somente na forma desmembrada em Física, Química e Biologia.

Interessante notar ainda que as disciplinas complementares que poderiam ser escolhidas pelas escolas, e as práticas educativas, para o Ginasial, vão na direção da profissionalização; já para o Colegial, há um amálgama de disciplinas de conteúdos culturais sistematizados e profissionalizantes, com prevalência do cultural sistematizado.

Embora, pelo texto da Lei, tenha-se descentralizado parte do currículo, as listas de disciplinas complementares indicadas pelo CFE para o sistema federal de ensino foram sugeridas também para os sistemas estaduais, uma vez que os Conselhos Estaduais ainda não haviam sido formados. (BRASIL, 1962, Art. $\left.3^{\circ}, \int 1^{\circ}\right)$. Além das listas de disciplinas, a Indicação s/n. de fevereiro de 1962 apresentou também sugestões de organização curricular denominadas "Variedades 
admissíveis". Em dois quadros, um para cada nível de ensino, indicou as cinco disciplinas obrigatórias para todo o sistema de ensino, e sugestões de disciplinas complementares para o Sistema Federal de Ensino, conforme a seguir:

Quadro 1. Quadro de variedades admissíveis para a organização curricular do ciclo Ginasial na Indicação s/n. de Fevereiro de 1962

\begin{tabular}{|c|c|c|c|c|c|c|c|c|c|c|c|c|c|c|c|c|c|c|}
\hline & & \multicolumn{17}{|c|}{ CICLO GINASIAL (Variedades admissíveis) } \\
\hline & & \multirow{2}{*}{ Séries } & \multicolumn{4}{|c|}{$1^{\text {a }}$ hipótese } & \multicolumn{4}{|c|}{$2^{\mathrm{a}}$ hipótese } & \multicolumn{4}{|c|}{$3^{a}$ hipótese } & \multicolumn{4}{|c|}{$4^{\mathrm{a}}$ hipótese } \\
\hline & & & I & II & III & IV & I & II & III & IV & I & II & III & IV & 1 & II & III & IV \\
\hline \multirow{6}{*}{$\begin{array}{c}\text { Disciplinas } \\
\text { indicadas } \\
\text { pelo } \\
\text { Conselho } \\
\text { Federal }\end{array}$} & 1 & Português & $x$ & $\mathrm{x}$ & $\mathrm{x}$ & $\mathrm{x}$ & $\mathrm{x}$ & $\mathrm{x}$ & $\mathrm{x}$ & $x$ & $\mathrm{x}$ & $\mathrm{x}$ & $\mathrm{x}$ & $\mathrm{x}$ & $x$ & $\mathrm{x}$ & $\mathrm{x}$ & $\mathrm{x}$ \\
\hline & 2 & História & $x$ & $x$ & $x$ & $\mathrm{x}$ & $x$ & $x$ & $x$ & $x$ & $x$ & $x$ & $x$ & $x$ & $x$ & $x$ & $x$ & $x$ \\
\hline & 3 & Geografia & $x$ & $x$ & $x$ & - & $x$ & $x$ & $x$ & - & $\mathrm{x}$ & $x$ & $x$ & - & $x$ & $x$ & $x$ & - \\
\hline & 4 & Matemática & $x$ & $x$ & $x$ & $x$ & $x$ & $x$ & $x$ & $x$ & $x$ & $x$ & $x$ & $x$ & $x$ & $x$ & $x$ & $x$ \\
\hline & \multirow{2}{*}{5} & Ciências & $x$ & $x$ & - & - & $x$ & $x$ & - & - & $x$ & $x$ & - & - & $x$ & $x$ & - & - \\
\hline & & $\begin{array}{l}\text { (Iniciação a Ciências } \\
\text { ou C. Fís. e Biol.) }\end{array}$ & - & - & - & $x$ & - & - & - & $x$ & - & - & - & $x$ & - & - & - & $x$ \\
\hline \multirow{5}{*}{\multicolumn{2}{|c|}{$\begin{array}{l}\text { Disciplinas } \\
\text { Complemen- } \\
\text { tares do } \\
\text { Sistema } \\
\text { Federal }\end{array}$}} & $\begin{array}{l}\text { Organiz. Social e } \\
\text { política brasil. }\end{array}$ & - & - & $\mathrm{x}$ & $x$ & - & - & - & - & - & - & - & - & - & - & - & - \\
\hline & & 1a. L. estr. mod. & - & - & - & - & - & - & $x$ & $x$ & - & - & $x$ & $x$ & - & - & $\mathrm{x}$ & $\mathrm{x}$ \\
\hline & & 2a. L. estr. mod. & - & - & - & - & - & - & - & - & - & - & - & - & - & - & $x$ & $x$ \\
\hline & & Língua Clássica & - & - & - & - & - & - & - & - & - & - & $\mathrm{x}$ & $x$ & - & - & - & - \\
\hline & & Desenho & - & - & $x$ & $x$ & - & - & $x$ & $x$ & - & - & - & - & - & - & - & - \\
\hline \multirow{2}{*}{\multicolumn{2}{|c|}{$\begin{array}{l}\text { Disciplinas } \\
\text { indicadas pelos } \\
\text { estabeleci- } \\
\text { mentos }\end{array}$}} & 1a. optativa & $x$ & $x$ & - & - & $x$ & $x$ & - & - & $x$ & $x$ & - & - & $x$ & $x$ & - & - \\
\hline & & 2a. optativa & - & - & $x$ & $\mathrm{x}$ & - & - & $x$ & $\mathrm{x}$ & - & - & $x$ & $x$ & - & - & $\mathrm{x}$ & $x$ \\
\hline
\end{tabular}

Fonte: BRASIL (1962a, p. 4558) 
Quadro 2. Quadro exemplificativo de variedades admissíveis para a organização curricular do ciclo Colegial na Indicação s/nº de Fevereiro de 1962

\begin{tabular}{|c|c|c|c|c|c|c|c|c|c|}
\hline & \multicolumn{9}{|c|}{$\begin{array}{l}\text { CICLO COLEGIAL (Variedades admissíveis) } \\
\text { (1 } 1^{\mathrm{a}} \text { e } 2^{\mathrm{a}} \text { séries) }\end{array}$} \\
\hline & \multirow{2}{*}{$\stackrel{\text { Séries }}{\longrightarrow}$} & \multicolumn{2}{|c|}{$1^{\mathrm{a}}$ hipótese } & \multicolumn{2}{|c|}{$2^{\mathrm{a}}$ hipótese } & \multicolumn{2}{|c|}{$3^{a}$ hipótese } & \multicolumn{2}{|c|}{$4^{\mathrm{a}}$ hipótese } \\
\hline & & I & II & I & II & I & II & I & II \\
\hline \multirow{5}{*}{$\begin{array}{l}\text { Disciplinas } \\
\text { indicadas } \\
\text { pelo } \\
\text { Cons. Federal }\end{array}$} & Português & $x$ & $x$ & $x$ & $x$ & $x$ & $x$ & $x$ & $x$ \\
\hline & História & $x$ & $x$ & $x$ & $x$ & $x$ & $x$ & $x$ & $x$ \\
\hline & Geografia & - & - & $x$ & $x$ & $x$ & - & $x$ & - \\
\hline & Matemática & $x$ & $x$ & - & - & - & - & - & - \\
\hline & C. Fís. e Biol. & - & - & $x$ & $x$ & - & $x$ & $x$ & $x$ \\
\hline \multirow{7}{*}{$\begin{array}{c}\text { Disciplinas } \\
\text { Complementares } \\
\text { do } \\
\text { Sistema } \\
\text { Federal }\end{array}$} & Física & $x$ & $x$ & - & - & - & - & - & - \\
\hline & Química & $x$ & $x$ & - & - & - & - & - & - \\
\hline & Biologia & $x$ & $x$ & - & - & - & - & - & - \\
\hline & Filosofia & - & - & - & - & - & - & $x$ & $x$ \\
\hline & L. estr. mod. & - & - & $x$ & $x$ & $x$ & $x$ & $x$ & $x$ \\
\hline & L. clássica & - & - & - & - & $x$ & $x$ & - & - \\
\hline & Desenho & - & - & $x$ & $x$ & - & - & - & - \\
\hline \multirow{2}{*}{$\begin{array}{c}\text { Disciplinas } \\
\text { indicadas pelos } \\
\text { estabelecimentos }\end{array}$} & 1a. optativa & $x$ & - & $x$ & - & $x$ & $x$ & - & $x$ \\
\hline & 2a. optativa & - & $x$ & - & $x$ & $x$ & $x$ & $x$ & $x$ \\
\hline
\end{tabular}

Fonte: BRASIL (1962a, p. 4558)

Nos quadros acima, no espaço que consta as "Disciplinas Complementares do Sistema Federal", quando se tratasse de sistemas estaduais, deveria conter as disciplinas complementares indicadas pelos Conselhos Estaduais.

$\mathrm{Na}$ Indicação, previu-se a abertura para que os sistemas estaduais e suas escolas pudessem eleger disciplinas do grupo das obrigatórias de um tipo de currículo, para configurar como optativas em outro tipo. (BRASIL, 1962a, Art. 5, Parágrafo único, p. 4557).

Ao flexibilizar alguns princípios de organização curricular, a LDB/1961 deu abertura para a elaboração de reformas em nível estadual para os Estados da federação. Localizamos reformas (ou reestruturação de currículos) para o ensino secundário somente do Estado de São Paulo (1963 e 1968) e do Estado do Paraná (1962), na vigência da LDB/1961. Interessante notar que, nas organizações do currículo do ensino Colegial nas reformas ocorridas nesses dois Estados, ainda no início da década de 1960, manteve-se alguns padrões similares à sistemática 
anterior à LDB, no que se refere às orientações de curso; ao que parece, visando diferentes possibilidades de prosseguimento nos estudos.

No caso do Estado de São Paulo, a organização curricular dos Ginásio Único Pluricurricular (GUP), criados em 1963, subdividia em Colegial Técnico, Colegial de Formação de Professores Primários e Colegial Secundário. Para este último, apresentavam-se três opções de orientações de curso denominadas "eclética, científica e clássica". O texto da reforma deixava subentendido que na primeira orientação havia um equilíbrio quantitativo de disciplinas científicas e humanidades; na segunda, predominavam as disciplinas científicas, e, na terceira de orientação clássica, as de humanidades. (SÃO PAULO, 1963). Em outra reforma, dessa vez mais geral para o ensino médio Colegial Secundário e Normal, ocorrida em 1968/1969, ainda que seguindo a linha dos GUP, esses termos deixam de denominar as diferentes opções de organização curricular propostas no texto da norma. (SÃO PAULO, 1969).

Quanto ao Estado do Paraná, na reestruturação curricular ocorrida em 1962, o currículo do Colegial foi organizado em Educação Geral e Profissionalizante, de modo que a primeira se dividia em orientações clássica e científica. Diferentemente do segundo ciclo da Reforma Capanema, na orientação clássica não trazia disciplinas científicas em nenhuma série, conforme mostraremos mais adiante.

\section{Uma nova reforma}

Para a viabilidade do modelo desenvolvimentista adotado pelos militares, a educação foi vista como expediente de grande relevância, uma vez que a modernização da economia pautada na industrialização crescente, e positivamente afetada pelo desenvolvimento tecnológico, demandava recursos humanos com formação mais especializada. Uma educação atrelada aos interesses da ordem social vigente. Ou seja, uma educação menos liberal e mais tecnicista, que pudesse servir ao projeto político e econômico (ROMANELLI, 1985).

Com esse objetivo, o Governo Militar realizou, a partir de 1964, acordos com os Estados Unidos ampliando ainda mais a participação internacional na gerência do país. São os famosos acordos entre o Ministério da Educação e Cultura - MEC e a Agency for International Development dos Estados Unidos - AID, os acordos MEC-USAID (ROMANELLI, 1985).

Convém ressaltar que a influência americana nos diversos setores do país, no que inclui também a Educação, por meio de acordos e projetos, já vinha ocorrendo de longa data, inclusive no período em que vivificou o "extremo" nacionalismo de Getúlio Vargas (MOREIRA, 2001).

Conforme descreve Romanelli (1985), foram assinados, ao todo, doze acordos entre o MEC e seus órgãos vinculados e a AID nos períodos de 1964 a 1968 , abrangendo todo o sistema de ensino, do nível primário ao superior, bem como os ramos acadêmicos e profissionais, com maior atenção ao acadêmico. Submeteu-se o sistema educacional a uma reestruturação administrativa de caráter empresarial, trazendo para a Educação concepções tayloristas de planejamento, racionalidade técnica, eficiência, produtividade e controle. De um modo geral, esses acordos envolviam assessoria técnica americana, com treinamento de pessoal docente e técnico brasileiros no Brasil e nos Estados Unidos, objetivando o planejamento 
do ensino, elaboração de planos específicos e outras ações de natureza técnica e pedagógica. Alguns desses acordos visavam ainda um "melhor entrosamento" entre os diferentes níveis de ensino. Os alcances dessa intervenção externa afetaram ainda, sobremaneira, o currículo nas escolas por meio de um acordo específico que visava o "controle do conteúdo geral do ensino através do controle de publicação e distribuição de livros técnicos e didáticos.” (ROMANELLI, 1985, p. 213).

Dentre os doze acordos assinados, quatro, explicitamente, mencionavam o ensino médio (ou ensino secundário), entretanto, todos contemplavam medidas que, de alguma forma, abrangiam esse nível de ensino, uma vez que eles, "embora implicassem assistência a setores específicos, possuíam uma estrutura única, perceptível através de aspectos comuns" (ROMANELLI, 1985, p. 213).

Consubstanciada nesses acordos, uma nova reforma é promovida por meio da Lei no 5.692 , de 11 de agosto de 1971, que simplificou a divisão dos graus de ensino da escola brasileira, unindo a escola primária com o primeiro ciclo da escola média (o Ginasial), denominando tal junção de $1^{\circ}$ grau, com duração de 8 anos, e eliminou o exame de admissão que conferia acesso entre tais níveis. Todos os cursos de grau Colegial - secundário, escolas profissionais e escolas normais - foram transformados em $2^{\circ}$ grau, passando este a ter caráter de profissionalização compulsória. O ensino de $1^{\circ}$ grau também se revestiu de um aspecto técnico, obrigatoriamente, constituindose numa iniciação para o trabalho, nas suas séries finais. (BRASIL, 1971a).

Essa reforma alterou profundamente a política curricular da escola brasileira, trazendo novas configurações para as entidades do currículo, tradicionalmente denominadas disciplinas ou matérias.

Segundo Nagle (1973), o currículo passou a ter um sentido mais amplo. O termo matéria passou a englobar as disciplinas, áreas de estudo e atividades. Conforme traz o Parecer no 853/1971 (o primeiro dos vários textos legais que suplementaram a reforma de 1971), disciplina tinha o sentido que sempre teve - conhecimento sistematizado - e foi recomendado que a aprendizagem se desenvolvesse predominantemente sob essa perspectiva. As áreas de estudo se referiam à integração de conteúdos afins de modo que a aprendizagem ocorresse pelo equilíbrio entre a experiência vivida pelo estudante e o conhecimento da cultura sistematizada. As atividades se definiriam pela aprendizagem a partir do conhecimento cotidiano, do palpável, do global ao micro. As atividades nasceriam das combinações entre as áreas de estudo formadas pelas combinações das disciplinas. (BRASIL, 1971b).

Nos termos da Lei 5.692/1971, o currículo pleno para o ensino de $1^{\circ}$ e $2^{\circ}$ graus se compunha de duas partes, educação geral e formação especial, organizadas em unidades maiores denominadas matérias. A Lei determinou que a educação geral fosse exclusiva nas séries iniciais do ensino de $1^{\circ}$ grau, e predominante nas séries finais. Quanto ao $2^{\circ}$ grau, deveria predominar a formação especial. (BRASIL, 1971a, Art. $5^{\circ}$ ).

A educação geral acomodou um núcleo comum, obrigatório em âmbito nacional, e uma parte diversificada de escolha livre pelas escolas. A formação especial se referia aos conteúdos curriculares voltados para a formação profissionalizante.

O CFE, por meio da Resolução n 08/1971, determinou para o núcleo comum, três matérias: Comunicação e Expressão, Estudos Sociais e Ciências. Estas foram subdivididas em conteúdos específicos que poderiam ser tratados como áreas de estudo, no $1^{\circ}$ grau, ou disciplinas, no $2^{\circ}$ grau (BRASIL, 1971c). No que 
concerne à formação especial ficou também a encargo do CFE fixar o mínimo exigido em cada habilitação profissional ou conjunto de habilitações afins, o que ocorreu por meio do Parecer no 45/1972.

Assim, Ciências ganhou status de matéria do núcleo comum da Educação Geral, subdividida nos conteúdos específicos, Matemática e Ciências Físicas e Biológicas (CFB), sendo este último subentendido na lei como uma integração das disciplinas científicas Física, Química e Biologia. Este conteúdo específico poderia ser desmembrado em disciplinas instrumentais na parte de formação especial (como conteúdo profissionalizante) (BRASIL, 1971c, Art. 5º Par. Único). Como disciplinas científicas específicas (Física, Química, Biologia) foram, posteriormente, sugeridas para a parte diversificada da educação geral (BRASIL, 1972), a presença destas no currículo seria de livre escolha pelos estabelecimentos de ensino.

\section{Status do "conhecimento científico" nas reformas em estudo}

O Artigo $1^{\circ}$ da LDB/1961 suscita conferir importância ao conhecimento científico como parte do contexto social do aluno, inserindo o tema como uma das finalidades da educação nacional: "o preparo do indivíduo e da sociedade para o domínio dos recursos científicos e tecnológicos que lhes permitam utilizar as possibilidades e vencer as dificuldades do meio". O Artigo 93 reforça essa importância ao preconizar que os recursos financeiros destinados ao sistema de ensino público deveriam assegurar, entre outras prioridades, "o desenvolvimento do ensino técnico-científico". (BRASIL, 1961).

Nesse contexto legislativo, as orientações para o currículo da Ciências da Natureza caminharam no sentido de conceber ao ensino de ciências características do processo de produção do conhecimento científico, ou seja, a simulação dos processos de investigação dos cientistas. Assim, idealizou-se o aluno como um pequeno cientista em sala de aula. Em um dos documentos de regulamentação da LDB/1961, denominado "Amplitudes e Desenvolvimento das Matérias Obrigatórias", traz para o ensino de ciências, que: "O essencial é a orientação didática do curso que deverá ter em vista o desenvolvimento de hábitos e atividades peculiares aos que se dedicam à pesquisa científica, principalmente à capacidade de iniciativa e de invenção”. (BRASIL, 1962e, p. 04-05).

As orientações reforçam a flexibilidade prevista na Lei, ao ressaltar a autonomia concedida ao professor ao ministrar a disciplina Ciências (e/ou Ciências Físicas e Biológicas), contrapondo às orientações rígidas e fechadas do sistema anterior à LDB.

Cumpre, finalmente, assinalar que deve ser dada ampla liberdade aos professores, por forma que possam ministrar a disciplina sem nenhuma preocupação de seguir normas pré-adotadas e o ensino se torne vivo e dinâmico e se ajuste aos interesses dos alunos e as variadas condições locais nas escolas das diferentes regiões do país. (BRASIL, 1962b, p. 04-05).

O texto da orientação indica defender o desmembramento da disciplina Ciências Físicas e Biológicas, ou seja, a adoção da primeira "hipótese admissível" do quadro de organização curricular sugerido pelo CFE (QUADRO 2): 
No $2^{\circ}$ ciclo, a diversificação da matéria Física, Química e Biologia, para os currículos que dão maior amplitude aos estudos científicos, permitirá a sistematização e o aprofundamento necessários à preparação dos alunos que desejam dedicar-se às carreiras de maior conteúdo de ciências experimentais. (BRASIL, 1962b, p. 04-05).

Esse trecho da orientação parece incitar, pelo menos em nível de propósito, a formação de futuros profissionais para atuarem na área de pesquisas científicas. Subentende-se o anseio por uma formação científica condizente com as demandas do contexto, seguramente, influenciadas por fatores político-econômicos e sociais internos e, principalmente, externos.

$\mathrm{Na}$ Reforma de 1971, o fato de Ciências ter se apresentado como uma das três entidades representativas do currículo do núcleo comum da Educação Geral, de certo modo, também inferiu importância ao conhecimento científico. Os objetivos almejados com o ensino dos conteúdos dessa matéria também pareceram reforçar esse ideário educativo com foco no ensino técnico-científico, pautado nos processos de desenvolvimento da ciência e na atividade dos cientistas: "O 'desenvolvimento do pensamento lógico e a vivência do método científico’, sem deixar de pôr em relevo as tecnologias que resultam de suas 'aplicações"'. (BRASIL, 1971b, Documenta $\mathrm{n}^{\circ} 132$, p. 177). Pretendeu-se para o estudante, o desenvolvimento do "espírito de investigação, invenção e iniciativa, o pensamento lógico e a noção da universalidade das leis científicas e matemáticas. [...]”. (BRASIL, 1971b, Documenta no 132, p. 179).

Os discursos das duas leis em questão se alinharam às tendências educativas do momento histórico, em que o ensino de Ciências ganhara destaque, em nível mundial, em um movimento que vinha ocorrendo desde meados de 1950. Tal movimento é justificado por diversos fatores, mas um se sobressai na história do ensino de Ciências no mundo: a concorrência pelo domínio ideológico, político, econômico e tecnológico do mundo por duas grandes potências: a propalada Guerra Fria entre os Estados Unidos e a União Soviética. Guerra esta, incandescida ainda mais por um evento de grande envergadura científico-tecnológica: o lançamento do primeiro satélite espacial, o Sputnik, em 1957, pela União Soviética. Fato que disseminou influências de diferentes ordens em vários países do mundo. (CHASSOT, 2004). A educação escolar passou a marcar o centro das atenções, especialmente a área de Ciências, em um movimento de resposta desencadeado pelo governo americano, que se encontrou em uma "crise de segurança nacional".

No Brasil, a exemplo de outros países do primeiro mundo, o projeto formativo, pelo menos em termos de discurso, perpassou pelo propósito de mudanças buscando alcançar uma ciência escolar mais sedutora, capaz de envolver o aluno, de convencê-lo da importância do conhecimento científico para o progresso do país, e até mesmo de atraí-lo para o campo das pesquisas em prol da nação. (ALMEIDA JUNIOR, 1979).

Embora na década de 1970, esse ideário tenha se revestido de um aspecto mais técnico, focando, principalmente, a formação de mão de obra para as diversas categorias ocupacionais decorrentes do processo de desenvolvimento do país, a ênfase no conhecimento científico ainda foi a "pedra de toque", a julgar pelos objetivos do ensino de ciências apregoados nas normas legais. 


\section{A PRESENCAA DAS DISCIPLINAS CIENTÍFICAS NOS DESDOBRAMENTOS DAS REFORMAS: DO DISCURSO AOS FATOS}

\section{Na LDB/1961}

Conforme trazem os quadros que orientaram a organização curricular nos termos da LDB/1961 (QUADROS 1 e 2 apresentados anteriormente), em todas as alternativas admissíveis sugeridas pelo CFE, a área de Ciências da Natureza está representada no ciclo ginasial em três das quatro séries, sendo contemplada em menor quantidade de séries do que a disciplina História.

No Colegial, as disciplinas da área são obrigatórias em até duas séries, sendo que uma "hipótese" (a terceira) de organização curricular, a Ciências está presente em somente uma série como Ciências Físicas e Biológicas (CFB). Somente uma hipótese sugerida para o Colegial traz a disciplina Ciências desdobrada em Física, Química e Biologia. Nas demais aparecem como CFB. Não há nenhuma alternativa em que Ciências apareça no limite máximo de quantidade de séries (6 séries), como prevê o Artigo $1^{\circ}$ da Indicação. Todas as demais disciplinas obrigatórias, em pelo menos uma alternativa, alcançam o limite máximo previsto.

Uma pesquisa realizada em 1963, pela Diretoria do Ensino Secundário (DES), do MEC, representados por Nádia Cunha e Jayme Abreu (1965) da Divisão e Estudos e Pesquisas Educacionais do Centro Brasileiro de Pesquisas Educacionais (CBPE) também reforça a ideia de que o ensino de Ciências não logrou evidência nos currículos escolares com o advento da LDB/1961. O levantamento da DES/MEC ocorreu com currículos ginasiais secundários de escolas particulares de várias partes do país, estruturados após a vigência da LDB. Foram analisados 1409 currículos, oferecidos por 1356 ginásios secundários da rede particular, o que, naquela época, correspondia a 53,1\% do total de colégios da rede particular do país. (CUNHA; ABREU, 1965, p. 308).

Cunha e Abreu (1965) apresentam quadros que nos revelam o lugar das Ciências nos currículos analisados. A partir desses quadros, elaboramos uma síntese dos dados por eles apresentados. 
As disciplinas científicas do Ensino Básico na Legislação Educacional Brasileira nos anos de 1960 e 1970

Quadro 3. Síntese de dados sobre as cargas horárias semanal das disciplinas e prática educativa obrigatórias nos currículos analisados por Cunha e Abreu (1965).

\begin{tabular}{|c|c|c|c|}
\hline $\begin{array}{c}\text { disciplinas } \\
\text { Obrigatórias }\end{array}$ & $\begin{array}{c}\text { \% sobre o total geral } \\
\text { da carga horária dos } \\
1409 \text { currículos }\end{array}$ & $\begin{array}{c}\text { Carga horária total } \\
\text { das } 4 \text { séries (em } \\
\text { horas) }^{3}\end{array}$ & $\begin{array}{c}\text { Carga horária por } \\
\text { série (em horas) }^{4}\end{array}$ \\
\hline Português & $29,6 \%$ & 20,0 & 5,00 \\
\hline Matemática & $25,5 \%$ & 16,3 & 4,00 \\
\hline História & $13,8 \%$ & 9,0 & $\mathbf{1 , 2 5}$ \\
\hline Ciências & $\mathbf{1 1 , 4 \%}$ & $\mathbf{7 , 1 2}$ & 1,75 \\
\hline Geografia & $10,9 \%$ & 7,0 & 1,35 \\
\hline $\begin{array}{c}\text { Prática Educativa } \\
\text { Obrigatória - } \\
\text { Educação Física }\end{array}$ & $8,8 \%$ & 5,4 & \\
\hline
\end{tabular}

Fonte: (CUNHA; ABREU, 1965, In: RBEP. v. 44, n. 100, 1965, grifo nosso).

Os dados denunciam a pouca ênfase dada à área, de modo que, das disciplinas obrigatórias, somente a Geografia possui carga horária inferior à Ciências: Fato evidenciado na análise dos autores: "Não deixa de ser assinalável a maior carga horária semanal dedicada à história em relação a ciências". (CUNHA; ABREU, 1965, p. 299).

Cunha e Abreu (1965) chamam a atenção ainda para a ausência de Ciências na terceira série do ensino ginasial, estando os currículos analisados consonantes com os quadros exemplificativos sugeridos pelo CFE na Indicação de Fevereiro/1962.

Além da questão da pouca Ciências nos currículos analisados, Cunha e Abreu (1965) evidenciam ainda a maciça presença do Latim em detrimento de disciplinas ou práticas educativas mais instrumentais. As críticas dos pesquisadores se assentam no ideário contextual de uma escola que carecia de estar identificada com o momento de mudança de modelo econômico que o Brasil vivenciava. Para Cunha e Abreu (1965), no contexto em questão, já não cabia mais um ensino erudito, sem funcionalidade prática.

Para efeito de ilustração e comparação sobre a presença das disciplinas científicas nas reformas educacionais de maior impacto, que precederam a LDB, ou seja, a de 1930 e 1942, apresentamos um quadro em anexo (ANEXO I). Analisando esse quadro, ao comparar a Indicação do CFE, com as reformas anteriores, nota-se que não houve aumento da presença da área de Ciências no currículo, principalmente quando se compara com a reforma de 1931, que indicava disciplinas da área em todas as séries do ensino secundário, com exceção para a opção do curso complementar Pré-jurídico, que só trazia uma disciplina da área em uma série. Em quantidade de séries anuais abrangidas por disciplinas da área de Ciências (como obrigatórias), eram seis ou sete na Reforma Francisco Campos, quatro ou cinco na Reforma Capanema (ambos os casos dependendo do curso do $2^{\circ}$ ciclo) e quatro ou cinco a partir de 1961 (dependendo da alternativa adotada dentre as variedades admissíveis) conforme as orientações do CFE. 
Observa-se, por exemplo, que, embora o ensino secundário a partir da LDB/1961 passasse a ter Ciências a partir do $1^{\circ}$ ano do ciclo Ginasial, não contemplou a disciplina em todas as séries desse ciclo, representando um acréscimo, em termos de presença, de somente uma série em relação ao currículo oficial anterior à LDB. No ciclo Colegial, disciplinas da área - Ciências Físicas e Biológicas ou as específicas Física, Química e Biologia - foram contempladas, como obrigatórias, em somente duas séries (antes da LDB apareciam em três séries). Assim, pode-se concluir que não houve aumento em termos de presença das disciplinas da Ciências da Natureza no currículo, quando se compara com a sistemática anterior.

Passaremos a alguns dados referentes a dois Estados brasileiros - São Paulo e Paraná - que nos permitem analisar a presença das disciplinas científicas nos currículos do ensino médio das escolas públicas brasileiras após a LDB/1961.

O primeiro exemplo que citaremos se refere à organização curricular do Ginásio Único Pluricurricular (GUP) criado no Estado de São Paulo, em 1963. Esses centros educacionais foram criados visando ministrar diversos cursos de grau médio com currículo organizado de forma a articular cultura geral e formação prática e profissional, compreendendo os cursos secundário, técnico (industrial, comercial, agrícola, de economia doméstica), artístico e de formação de professores primários (SÃO PAULO, 1963). A organização curricular do GUP foi dada pela Resolução no 07, de 23.12.1963, do Conselho de Educação do Estado de São Paulo (CEE/SP). Apresentam-se listas de disciplinas e orientações e quadros exemplificativos similares aos sugeridos pelo CFE, trazendo três alternativas para cada nível do ensino secundário.

Para o Ginasial, há somente opções de organização sem nenhuma orientação especial, exceto pela quantidade de séries da disciplina Geografia que, em uma das opções aparece em três séries, e nas demais, em duas. Quanto ao restante das disciplinas, em termos de séries, essas aparecem em quantidades iguais, variando a distribuição: Português e Matemática em todas as séries (em todas as orientações); História em três séries (em todas as orientações); Geografia em duas ou três, e CFB em duas séries (em todas as orientações).

Para o Colegial, as alternativas se referem às diferentes orientações de curso denominadas "eclética, científica e clássica". ${ }^{5} \mathrm{Na}$ primeira há um equilíbrio quantitativo de disciplinas científicas e humanidades. Na segunda, predominam as disciplinas científicas, e, na terceira, as de humanidades. Conforme consta no texto da Resolução nº 07/CEE-SP/1963, Ciências Físicas e Biológicas está presente da seguinte forma:

- Ciclo Ginasial: obrigatória (Iniciação a ciências) em duas séries $\left(1^{\mathrm{a}}\right.$ e $\left.2^{\mathrm{a}}\right)$ em todas as opções sugeridas;

- Curso Colegial Secundário: obrigatória nas orientações "eclético” e "clássico", em uma série $\left(2^{a}\right)$, e na orientação "científico", em duas séries $\left(1^{\mathrm{a}}\right.$ e $\left.2^{\mathrm{a}}\right)$

- Curso Colegial Técnico Industrial: obrigatória em uma série (apresenta um quadro exemplificativo que sugere na $1^{\mathrm{a}}$ série);

- Curso Colegial Técnico Comercial: como uma sugestão de escolha para optativa, concorrendo com Língua Moderna, Filosofia, Sociologia e Desenho;

- Curso Colegial de Formação de Professores Primários: como obrigatória 
em uma série (sugere na 1ª série). (RBEP, v. 44, n.100, 1965, p. 108-111).

As orientações para o GUP não apresentam carga horária para as disciplinas, e nos permitem conclusões somente quanto à presença de Ciências no currículo em termos de número de séries contempladas em todo o ensino secundário. Essas informações revelam que Ciências angariou o menor espaço dentre todas as disciplinas obrigatórias do currículo. Fato que corrobora a constatação de Cunha e Abreu (1965).

$\mathrm{Na}$ Reforma de 1968, também do Estado de São Paulo, desta vez para todos os cursos do ensino médio Colegial Secundário e Normal (Lei Estadual n ${ }^{\circ}$ 10.038/1968) é possível verificar, além da presença por série, também a carga horária semanal das disciplinas. Essa reforma, inspirada na linha do GUP, criou os Colégios Integrados, com organização de currículo comum nas duas primeiras séries do ensino Secundário e Normal para todos os estabelecimentos de ensino oficiais e particulares do Estado de São Paulo. Apresentou, imperativamente, quatro possibilidades de organização do currículo, com determinação expressa de adoção de apenas uma das opções apresentadas (Ato n ${ }^{\circ} 24$ de 29.02.1969). As opções dadas foram:

I - Português, Matemática, Geografia, História, Ciências Físicas e Biológicas, uma língua [Latim, Francês ou Inglês] e uma disciplina optativa.

II - Português, Matemática, Geografia, História, uma Ciência Física ou Biológica, uma língua [Latim, Francês ou Inglês] e uma disciplina optativa.

III - Português, Matemática, Estudos Sociais, Ciências Físicas e Biológicas, uma língua [Latim, Francês ou Inglês] e uma disciplina optativa.

IV - Português, Matemática, Estudos Sociais, uma Ciência Física ou Biológica, uma língua [Latim, Francês ou Inglês] e uma disciplina optativa. (SÃO PAULO, 1969, Art. $2^{\circ}$ ).

Em duas opções têm-se Ciências Físicas e Biológicas, e em outras duas, "uma Ciência Física ou Biológica" como disciplinas obrigatórias. Elegendo as opções II ou IV, o currículo poderia ter somente umas das três disciplinas científicas, conforme consta: "A ciência Física ou Biológica, referida nos incisos II e IV deste artigo, será uma das seguintes: Física, Química, Biologia”. (SÃO PAULO, 1969, Art. $2^{\circ}, \int 2^{\circ}$. Desse modo, ao mencionar "uma ciência física" nas opções II e IV, deu-se a opção de compor o quadro curricular contendo Física ou Química, e não as duas (ambas são de natureza física).

Quanto à carga horária, o Artigo $7^{\circ}$ do referido Ato, indica para as duas primeiras séries, a carga horária semanal mínima:
a) Português - três aulas em cada série.
b) Matemática - duas aulas em cada série.
c) Geografia - duas aulas em cada série.
d) História - duas aulas em cada série. 
e) Estudos Sociais - quatro aulas em cada série.

f) Ciências Físicas e Biológicas - quatro aulas em cada série.

g) Disciplina científica isolada (caso previsto no parágrafo $2^{\circ}$ do Artigo $2^{\circ}$ ) - três aulas em cada série.

h) Língua - duas aulas em cada série.

i) Cada disciplina optativa - duas aulas em cada série. (SÃO PAULO, 1969, Art. $7^{\circ}$ ).

Adotando as opções que trazem CFB, a carga horária de 4 aulas semanais para a mesma configuraria uma média de 1,33 aulas para atividades de cada "subdisciplina” (Física, Química, Biologia), caso as atividades de tal disciplina fossem assim desenvolvidas em sala de aula. Estando CFB imbuída na ideia de "área de estudo" nessa legislação, é admissível pressupor que, em sala de aula, uma ou outra subárea tenha sido privilegiada, ficando a mercê das possibilidades pedagógicas e estruturais das escolas.

$\mathrm{O}$ segundo exemplo se refere à reestruturação curricular do Estado do Paraná, em 1962, que também traz diferentes orientações de curso, clássica e científica. Nesta, o ensino de Ciências está presente no Ginasial seguindo a orientação do CFE (três séries $-1^{\mathrm{a}}, 2^{\mathrm{a}}$ e $4^{\mathrm{a}}$ ) variando a carga horária de 2 a 3 aulas semanais.

No Colegial, na orientação clássica não tinha disciplinas das Ciências; na orientação científica trouxe Física nas três séries (diurno e noturno) com 3 aulas em cada uma; Química com 2, 2 e 3 aulas, respectivamente, nas três séries, diurno e noturno; e Biologia - nas $2^{\mathrm{a}}$ e $3^{\mathrm{a}}$ séries, diurno com 3 aulas em cada série e noturno com 2 aulas. No Colegial Normal havia "Ciências" nas $1^{\mathrm{a}}$ e $2^{\mathrm{a}}$ séries, diurno com 3 aulas em cada série e noturno com 2 aulas em cada. No Colegial TécnicoComercial apresenta CFB somente na $1^{\mathrm{a}}$ série com 2 aulas, diurno e noturno. Observa-se nessa organização curricular que as aulas de Ciências variavam entre 2 e 3 aulas semanais, dependendo do curso/orientação e do turno.

Quanto à presença nas séries, variavam de 0 a 3 séries. No Ginasial seguiramse à risca as sugestões do CFE (Indicação de Fevereiro/1962) não contemplando Ciências na $3^{a}$ série. Outra observação notável na grade curricular, é que, corroborando as conclusões de Cunha e Abreu (1965) com as escolas particulares, as Ciências se apresentaram em menor evidência em relação a todas as demais disciplinas obrigatórias, ou seja, ocupou a última posição em termos de presença e carga horária. No Colegial, a situação não se diferiu dos demais exemplos já citados.

\section{Na Lei 5692/1971}

As modificações nas diretrizes da educação trazidas com a Lei 5692/1971 mudaram substancialmente a configuração e distribuição/carga horária das disciplinas da área de Ciências para se ajustarem ao modelo de ensino adotado, voltado para a formação profissional. 
No Estado do Paraná, os quadros curriculares de 1971 (TENÓRIO, 2009), após a sanção da Lei 5692/1971, trazem para o Curso Normal, por exemplo, a Física, a Química e a Biologia somente na $1^{\text {a }}$ série e com 2 aulas semanais, no núcleo comum da Educação Geral. Para um curso da área Industrial, têm-se CFB no núcleo comum com carga horária total de 270 horas para todo o curso. Esse quantitativo equivale a uma distribuição média de 3 aulas semanais por série. Enfim, 3 aulas semanais para trabalhar assuntos de Física, Química e Biologia.

Ainda para esse curso, que consideramos um caso bem peculiar, contempla a Física e a Química como disciplinas da parte diversificada da Formação Especial com 120 e 90 horas total, respectivamente. Esse quantitativo corresponde para a Física, por exemplo, a 4 aulas semanais distribuídas nas três séries, o que corresponde uma média semanal por série de 1.33 aulas (caberia a seguinte distribuição: 4 aulas acumuladas em uma série; ou $2+2$ ou $3+1$ em duas séries; ou 2+1+1 em três séries).

Para o Curso Técnico em Agropecuária, apresentam Física, Química e Biologia, no núcleo comum da Educação Geral, com cargas horárias de 2 aulas nas $1^{\mathrm{a}}$ e $2^{\mathrm{a}}$ séries e 1 aula semanal na $3^{\mathrm{a}}$ série.

Caju (2005) traz em seu trabalho grades curriculares de alguns cursos técnicos de uma escola do Estado do Rio de Janeiro, referente ao ano de 1973. A Física vem como disciplina específica na parte de Educação Geral com 2 aulas semanais nas $1^{\mathrm{a}}$ e $2^{\mathrm{a}}$ séries, assim como a Química e a Biologia. Os quadros apresentados pela autora não mostram a separação entre disciplinas do núcleo comum e parte diversificada da Educação Geral. Também, o Projeto de Reformulação de Currículos do Estado do Rio de Janeiro - 2º grau (1976; 1977) mostra que em 1977 a situação da disciplina no currículo permaneceu a mesma. O documento traz a grade curricular contendo as disciplinas de educação geral e parte da formação especial (denominada instrumental), e, em separado, as grades curriculares de 10 habilitações adotadas pela Secretaria de Estado de Educação e Cultura.

$\mathrm{Na}$ grade curricular, a CFB aparece desdobrada em disciplinas específicas - Física, Química e Biologia - no núcleo comum, com cargas horárias semanais de 2 aulas em cada série, estando Física e Química presente nas três séries e Biologia somente na $1^{\mathrm{a}}$ e $2^{\mathrm{a}}$ séries. A Física se faz presente, fragmentada, na Formação Especial na Habilitação Básica de Eletricidade, sob nome Eletricidade, com carga horária semanal de 4 e 6 horas, nas $2^{a}$ e $3^{a}$ séries, respectivamente. Nas demais habilitações básicas, não apresentam a Física e nem CFB.

No caso do Estado de São Paulo, tivemos acesso somente ao currículo de Física do $2^{\circ}$ grau, de 1978 , e esta aparece também como disciplina desdobrada das CFB no núcleo comum, com 2 aulas semanais nas $1^{\text {a }}$ séries de todas as habilitações e modalidades de Formação Profissionalizante, e com 2 aulas semanais na $2^{a}$ série na Formação Profissionalizante Básica, Setor Terciário e Habilitação do $2^{\circ}$ grau Magistério.

Para a Formação Profissionalizante Básica do Setor Primário, aparece a partir da $2^{\mathrm{a}}$ série como disciplina instrumental, Física Aplicada, com 3 aulas semanais em cada série. Para a Formação Profissionalizante Básica do Setor Secundário, temse a Física Aplicada nas $3^{\mathrm{a}}$ e $4^{\mathrm{a}}$ séries, com 3 e 4 aulas semanais, respectivamente; e como disciplina específica profissionalizante Eletricidade na $3^{\text {a }}$ série desta mesma formação básica, com 2 aulas semanais. (SÃO PAULO, 1978, p. 9-10). 
Como se depreende dos exemplos citados, as disciplinas científicas específicas, a partir da Lei 5.692/1971, aparecem com carga horária relativamente pequena, na maioria dos casos, duas aulas semanais em cada série.

\section{CONSIDERAÇ̃̃ES FINAIS}

Encontra-se em textos da literatura recente a afirmação de que, nos anos de 1960, com o advento da LDB/1961, houve ampliação no ensino da Ciências da Natureza no currículo da educação básica (ABRANTES, 2008; BOCASANTA, 2013; RODRIGUES, 2013, outros). De um modo geral, esses autores se referenciam em Krasilchik (2000, p. 86) que afirma que a LDB/1961 "ampliou bastante a participação das ciências no currículo escolar, que passaram a figurar desde o $1^{\circ}$ ano do curso ginasial." A autora afirma ainda, ter havido um "substancial aumento da carga horária de Física, Química e Biologia" no Curso Colegial (KRASILCHIK, 2000, p. 86). Em contrassenso a estas afirmações, os resultados apresentados neste estudo admitem a ideia de que não se deu evidência às disciplinas científicas em termos de presença e carga horária nos currículos do ensino secundário, como suscitaram as legislações maiores (LDB/1961 e Lei 5.692/1971) aqui analisadas, bem como afirmam os autores mencionados.

A comparação da distribuição de carga horária e presença da Ciências da Natureza nos currículos citados, com as duas reformas educacionais nacionais imediatamente precedentes à LDB/1961 (Reforma Francisco Campos e Reforma Capanema), nos indica que o discurso das leis quanto à importância do conhecimento científico nelas concebida não foi efetivado por meio das instruções e normas educacionais que as regulamentaram.

Contudo, deve-se reconhecer um importante mérito da LDB/1961, que refletiu de forma positiva no ensino de ciências no Brasil: a abertura para experiências educacionais (BRASIL, 1961. Art. 20) antes limitadas pelos preceitos das legislações anteriores. Tal abertura, junto a outros fatores de abrangência maior, contribuiu para que ocorressem importantes tentativas de melhoria na área de ensino de Ciências no Brasil e que redefiniram o papel atribuído às disciplinas científicas no período em questão.

O fato de Ciências ter sido destacada como uma das três matérias fixadas para a educação geral, com o advento da Lei 5.692/1971, também não significou aumento de carga horária de seus conteúdos específicos, Matemática e Ciências Físicas e Biológicas (CFB), ou das disciplinas desdobradas de CFB: Física, Química e Biologia. Pelo contrário, em alguns casos, as disciplinas (ou "subáreas" como foi desmembrada nos currículos) sofreram redução de carga horária para ajustes dos quadros curriculares, devido à inserção de disciplinas da parte de formação especial, com a finalidade de atender às habilitações profissionais adotadas pelas escolas (ou pelas secretarias estaduais). Novamente, os discursos da Lei e suas normas não se efetivaram. Não se deu realce às disciplinas que, em tese, levariam à formação de uma cultura científica condizente com as questões sociais que se faziam presentes. Além dos avanços científicos e tecnológicos que se processavam no mundo, outras questões decorrentes disso se impunham como necessidade de discussões, passando a demandar uma atenção maior às disciplinas da área de Ciências. 
Ao que parece, as influências externas que permearam as reformas aqui analisadas não foram, de fato, compreendidas na implementação das leis do período analisado. Conforme citamos neste texto, as reformas em questão foram substanciadas por acordos políticos/econômicos com os Estados Unidos; país que liderava naquele contexto histórico o movimento renovador para o ensino de ciências. Uma outra análise realizada em materiais de ensino utilizados no Brasil do período em questão, alguns deles elaborados nos Estados Unidos, nos leva a entender que o ideário de ensino de ciências do país influenciador pressupunha um viés mais estético; a compreensão da natureza bela, com suas leis e regularidades, o trabalho do cientista, a observação dos fenômenos, a pesquisa de laboratório.

Esse modelo de "conhecimento científico" traz a dependência de maior tempo de atividades escolares, melhores estruturas físicas das escolas (laboratórios, equipamentos para experimentação e de multimídias, etc.) e maior capacidade de ensino por parte dos professores. Ao passo que, no Brasil, a ciência "necessária" ao projeto desenvolvimentista, à formação de mão de obra, demandava um viés mais técnico, de aplicabilidade imediata, um conhecimento científico mais mercantilizado.

Em suma, apesar das intervenções americanas no sistema educacional brasileiro, onde se incluiu até mesmo capacitações técnicas para profissionais da Educação, o que se ensaiou foi um conhecimento científico híbrido - nem bem científico e nem bem tecnológico - configurando um jogo entre o antigo e o novo. Tal conflito ganhou reforço com a falta de estrutura das escolas e a precária formação dos professores para atender às configurações das disciplinas dos currículos nos termos inicialmente propostos nas leis, de modo que, o espaço concedido à Ciências da Natureza no currículo esteve diretamente ligado à capacidade de desenvolvimento das disciplinas científicas no contexto estrutural das escolas do país. Isso reforça as percepções de Goodson (1999) e Ball (2001) quando esses autores alertam para o distanciamento entre o que se propõe (ou se impõe) com as reformas (muitas vezes inspiradas em outros contextos) e as condições reais de aplicabilidade das mesmas.

Este trabalho, de cunho histórico, oferece elementos que incitam uma reflexão sobre as discussões atuais acerca da (re)estruturação do ensino médio, o Novo Ensino Médio, determinada inicialmente via Medida Provisória n ${ }^{\circ} 746$, de 22 de setembro de 2016 e convertida na Lei 13.415 de 16 de fevereiro de 2017. Nesta reforma, o currículo é composto por cinco áreas de conhecimento (itinerários formativos): Linguagens e suas tecnologias, Matemática e suas tecnologias, Ciências da Natureza e suas tecnologias, Ciências Humanas e Sociais Aplicadas e Formação técnica e profissional.

A composição curricular desses itinerários formativos compreende uma parte básica, correspondente a $60 \%$ da carga horária, composta por conteúdos da Base Nacional Curricular Comum (BNCC), que é outra "inovação" proposta para o sistema de ensino; e outra parte diversificada de escolha do aluno/escola, que poderá se concentrar em um dos cinco itinerários formativos (o da Formação técnica e profissional tem sido bastante enfatizado nos discursos de defesa desta "nova" reforma do ensino médio).

A proposta é de que a BNCC defina as competências específicas de cada área de conhecimento determinadas pela Lei, os componentes curriculares e as 
competências específicas dos componentes (conteúdo mínimo). A Lei 13.415/2017 definiu Língua Portuguesa e Matemática como componentes obrigatórios nos três anos do Ensino Médio. Os demais componentes obrigatórios, não necessariamente em todas a séries, serão definidos pela BNCC. A nova Lei determina o aumento gradativo da carga horária mínima anual de oitocentas horas (800) para mil e quatrocentas horas (1400) e se pauta na promessa do ensino de tempo integral.

A experiência histórica do sistema de ensino brasileiro nos permite vislumbrar os desdobramentos práticos desta reestruturação, que, em uma análise primária e superficial, a nosso ver, se mostra como uma nova roupagem da reforma de 1971.

\section{REFERÊNCIAS}

ABRANTES, A. C. S. Ciência, Educação e Sociedade: o caso do Instituto Brasileiro de Educação, Ciência e Cultura (IBECC). 2008. 287 f. Tese (Doutorado em História das Ciências e da Saúde) Casa de Oswaldo Cruz/Fiocruz, Rio de Janeiro, 2008.

APPLE, M. W. Conhecimento Oficial: A Educação Democrática Numa Era Conservadora. Tradução de Maria Isabel Edelweis Bujes. Petrópolis, RJ: Vozes, 1997.

BALL, Stephen. Diretrizes políticas globais e relações políticas locais em educação. Currículo sem fronteiras, v. 1, n. 2, jul./dez, 2001, p. 99-116. Disponível em: <www.curriculosemfronteiras.org>. Acesso em: 07 Ago. 2018.

BOCASANTA, D. M.. Dispositivo da tecnocientificidade: a iniciação científica ao alcance de todos. 2013. 233f. Tese (Doutorado). Unidade de Pesquisa e Pós-graduação, Universidade do Vale do Rio dos Sinos - UNISINOS, São Leopoldo.

BRASIL. Decreto-Lei n ${ }^{\circ} 4.244$ - Lei Orgânica do Ensino Secundário. D.O.U - Seção 1-10.04.1942, Página 5798 (Publicação Original). Disponível em: http://www2.camara.leg.br/legin/fed/ declei/1940-1949/decreto-lei-4244-9-abril-1942-414155-publicacaooriginal-1-pe.html. Acesso em: 10 Jan. 2015.

BRASIL. Lei 4.024/61. Fixa as Diretrizes e Bases da Educação Nacional. Diário Oficial da União de 20 de Dezembro de 1961.

BRASIL. Indicação $\mathrm{s} / \mathrm{n}^{\circ} / \mathbf{6 2}$ de 21-02-1962. Normas para o ensino médio nos termos da Lei 4024/61, MEC/CFE/CEMP. 1962a. Diário Oficial da União de 24 de abril de 1962.

BRASIL. Indicação s $/ \mathrm{n}^{\circ} / 62$, s.d. Amplitude e desenvolvimento das matérias obrigatórias, MEC/ CFE/CEMP. Documenta $\boldsymbol{n}^{\mathbf{0}}$ 8, out. 1962 e no 11, jan/fev. 1963. 1962b. Disponível em: http:// www.histedbr.fe.unicamp.br/. Acesso em 13 jan. 2015.

BRASIL. Lei $\mathbf{n}^{\circ} \mathbf{5 . 6 9 2}$ de $\mathbf{1 1}$ de agosto de 1971. Fixa as diretrizes e bases para o ensino de $1 .^{\circ}$ e $2 .^{\circ}$ graus e dá outras providências, 1971.

BRASIL. CFE. Parecer no 853, de 12 de novembro de 1971, do CFE. Núcleo-comum para os currículos do ensino de $1^{\circ}$ e $2^{\circ}$ graus. A doutrina do currículo. In: Documenta $\mathbf{n}^{\circ} 132$, Rio de Janeiro, nov.1971b.

BRASIL. CFE. Resolução no 08, de 12 de novembro de 1971. Fixa o núcleo-comum para os currículos do ensino de $1^{\circ}$ e $2^{\circ}$ graus e a doutrina do currículo nos termos da Lei 5.692/1971. Documenta $\mathbf{n}^{o}$ 
133, Rio de Janeiro, dez.1971. 1971c Disponível em: http://www.histedbr.fe.unicamp.br/ . Acesso em: 10 out. 2014.

BRASIL. CFE. Parecer no 871, de 11 de agosto de 1972, do CFE. Matérias da parte diversificada do currículo do $1^{\circ}$ e $2^{\circ}$ graus, para o sistema federal. Documenta ${ }^{\circ}$ 141, Rio de Janeiro, Ago.1972. Disponível em: http://www.histedbr.fe.unicamp.br/ . Acesso em: 29 out. 2015.

BRASIL. Lei 13.415 de 16 de fevereiro de 2017. Altera dispositivos da Lei $\mathrm{n}^{\circ}$ 9.394, de 20 de dezembro de 1996 e Lei no 11.494, de 20 de junho 2007, e institui a Política de Fomento à Implementação de Escolas de Ensino Médio em Tempo Integral, 2017.

CAJU, V. Análise da disciplina sociologia na educação profissional: Reflexões a partir de um estudo de caso. 2005. Dissertação de Mestrado. Rio de Janeiro: Universidade Federal do Rio de Janeiro, 2005.

CHASSOT, A. O Ensino de ciências no começo da segunda metade do século da tecnologia. In: O currículo de ciências em debate. Campinas, SP: Papirus, 2004.

CUNHA, N.; ABREU, J. Currículo ginasial secundário no Brasil, depois da Lei de Diretrizes e Bases. In: Revista Brasileira de Estudos Pedagógicos, Rio de Janeiro, v. 44, n. 100, p. 295-309, out./dez. 1965.

FERRETTI, C. J. A inovação na perspectiva pedagógica. In: GARCIA, Walter. (coord.) Inovação educacional no Brasil: problemas e perspectivas. São Paulo: Cortez/Autores Associados, 1980.

FONTOURA, A. A reforma do ensino. Rio de Janeiro: Ed. Aurora, [1979?].

GOODSON, I. Currículo: teoria e história. Petrópolis: Vozes, 1995.

GOODSON, I. A crise da mudança curricular: algumas advertências sobre iniciativas de reestruturação. In: SILVA, H. L. (org.). Século XXI: qual conhecimento? qual currículo? Petrópolis: Vozes, 1999. p. 109-126.

KRASILCHIK, M. Reformas e realidade: o caso do ensino de Ciências. São Paulo em Perspectiva. v. 14, n. 1. São Paulo Jan./Mar. 2000, p. 85-93.

MOREIRA, A. F. B. Currículos e programas no Brasil. Campinas: Papirus, 2001.

NAGLE, J. A reforma e o ensino. São Paulo, EDART, 1973.

NAPOLITANO, M. A arte engajada e seus públicos (1955/1968). Estudos Históricos, Rio de Janeiro, n. 28, 2001, p. 103-124.

PARANÁ (Estado). Secretaria de Educação e Cultura. Currículos do Ensino Médio - Fixados pela S.E.C. para os estabelecimentos estaduais de ensino médio no ano letivo de 1962. Curitiba:1962.

PARANÁ (Estado). Secretaria de Educação e Cultura.. Articulação e Integração no Ensino de $1^{\circ}$ Grau (Diretrizes Teóricas dos Currículos de $5^{\mathrm{a}}$ e $6^{\mathrm{a}}$ séries do Ensino de $1^{\circ} \mathrm{Grau}$ ). Revista do Ensino. Porto Alegre, RG, n. 47, suplemento especial n. 4 -Educação no Paraná -, 1972.

RODRIGUES, M. A. Brincando de ser cientista: Uma forma lúdica de vivenciar o método científico. Lat. Am. J. Phys. Educ. v. 7, n. 1, March 2013.

ROMANELLI, O. de O. História da Educação no Brasil: 1930/1973. $7^{\text {a }}$ ed. Petrópolis: Vozes, 1985. 
SACRISTÁN, G. O Currículo, uma reflexão sobre a prática. Porto Alegre: Editora Artmed, 2000.

SÃO PAULO (Estado). Conselho Estadual de Educação. Resolução CEE/SP nº 36, de 30 de Dezembro de 1968, homologada pelo Ato ${ }^{\circ} 09$ de 10 de Janeiro de 1969. Estabelece normas para a organização do Colégio Integrado e do Ciclo Colegial secundário e normal, e dá outras providências. 1968c. Disponível em: http://www3.fe.usp.br/secoes/inst/novo/acervo_jmpa/PDF_SWF/28.pdf. Acesso em: 12 Mar. 2015.

SÃO PAULO (Estado). Conselho Estadual de Educação. Ato $\mathbf{n}^{\mathbf{0}}$ 24, de 29 de Janeiro de 1969. Baixa instruções para aplicação das normas estabelecidas pela Resolução CEE $n^{\circ} 36 / 38$, para as duas primeiras séries do ciclo colegial secundário e normal. Disponível em: http:/ /www3.fe.usp.br/ secoes/inst/novo/acervo_jmpa/PDF_SWF/28.pdf. Acesso em: 12 Mar. 2015.

SOUZA, R. F. História da organização do trabalho escolar e do currículo no Século XX: ensino primário e secundário no Brasil. São Paulo, SP: Cortez, 2008.

TENÓRIO, N. C. Curricularização da Moral e do Civismo no Ensino Médio no Estado do Paraná 1961-1971. Dissertação (Mestrado) - Universidade Federal de Mato Grosso do Sul, Programa de Pós-Graduação em Educação. Campo Grande, MS. UFMS, 2009. 161 f.

\section{NOTAS}

${ }^{1}$ Nesse período, o sistema educacional era regido pelos Decretos-Leis da Reforma iniciada por Gustavo Capanema, conforme já mencionado neste texto.

${ }^{2} \mathrm{Na} \mathrm{LDB} / 1961$, o termo "ensino médio" abrangia os cursos ginasial e colegial. Comparando com a organização do ensino básico atual, seria o equivalente ao Ensino Fundamental II + Ensino Médio.

${ }^{3}$ Dados aproximados.

${ }^{4}$ Modificamos a forma de apresentação dos dados de tempo "horas+minutos" para somente "horas", sem alteração dos valores apresentados nos quadros originais de Cunha e Abreu (1965). Dados aproximados.

${ }^{5} \mathrm{O}$ documento não explica o significado dessas orientações de cursos.

Submetido em 03/11/2017

Aprovado em 01/09/2018

\section{Contato:}

Maria Neuza Almeida Queiroz

Instituto Federal do Norte de Minas Gerais - Campus Pirapora

Av. Humberto Mallard, n. 1355 - Santos Dumont

CEP 39.270-000 - Pirapora, MG - Brasil 


\section{ANEXO I}

Quadro 4. Quadro comparativo da presença de disciplinas da área de Ciências nas reformas educacionais de 1932, 1942 e 1961

\begin{tabular}{|c|c|c|c|c|c|c|c|c|}
\hline \multicolumn{2}{|c|}{$\begin{array}{l}\text { REFORMA FRANCISCO } \\
\text { CAMPOS }(1931)\end{array}$} & \multicolumn{2}{|c|}{$\begin{array}{c}\text { REFORMA CAPANEMA } \\
\text { (1942) }\end{array}$} & \multicolumn{5}{|c|}{ LDB/1961 } \\
\hline \multicolumn{2}{|c|}{$\begin{array}{c}\text { Ciclo Fundamental } \\
\text { Ginasial }\end{array}$} & \multicolumn{2}{|c|}{ Primeiro Ciclo Ginasial } & \multicolumn{5}{|c|}{ Ciclo Ginasial } \\
\hline Séries & $\begin{array}{l}\text { Disciplinas } \\
\text { da área de } \\
\text { Ciências }\end{array}$ & Séries & $\begin{array}{l}\text { Disciplinas } \\
\text { da área de } \\
\text { Ciências }\end{array}$ & Séries & \multicolumn{4}{|c|}{$\begin{array}{l}\text { Disciplinas da área de Ciências nas quatro } \\
\text { hipóteses indicadas pelo CFE }\end{array}$} \\
\hline $1^{\mathrm{a}}$ & $\begin{array}{l}\text { Ciênc. físicas } \\
\text { e naturais }\end{array}$ & $1^{\mathrm{a}}$ & - & $1^{\mathrm{a}}$ & \multicolumn{4}{|c|}{ Iniciação à Ciência } \\
\hline $2^{\mathrm{a}}$ & $\begin{array}{l}\text { Ciênc. físicas } \\
\text { e naturais }\end{array}$ & $2^{a}$ & - & $2^{\mathrm{a}}$ & \multicolumn{4}{|c|}{ Iniciação à Ciência } \\
\hline $3^{\mathrm{a}}$ & $\begin{array}{l}\text { Física, Química } \\
\text { e Hist. Natural. }\end{array}$ & $3^{\mathrm{a}}$ & $\begin{array}{l}\text { Ciências } \\
\text { Naturais }\end{array}$ & $3^{a}$ & \multicolumn{4}{|c|}{-} \\
\hline $4^{\mathrm{a}}$ & $\begin{array}{l}\text { Física, Química } \\
\text { e Hist. Natural. }\end{array}$ & $4^{a}$ & $\begin{array}{l}\text { Ciências } \\
\text { Naturais }\end{array}$ & $4^{a}$ & \multicolumn{4}{|c|}{ Ciências Físicas e Biológicas } \\
\hline $5^{a}$ & $\begin{array}{l}\text { Física, Química } \\
\text { e Hist. Natural. }\end{array}$ & & & & & & & \\
\hline \multicolumn{2}{|c|}{ Ciclo Complementar } & \multicolumn{2}{|c|}{ Segundo Ciclo - Colegial } & \multicolumn{5}{|c|}{ Ciclo Colegial } \\
\hline Séries & $\begin{array}{c}\text { Curso/ } \\
\text { Disciplinas }\end{array}$ & \multirow[t]{2}{*}{ Séries } & $\begin{array}{c}\text { Curso/ } \\
\text { Disciplinas }\end{array}$ & \multirow[t]{2}{*}{ Séries } & \multicolumn{4}{|c|}{$\begin{array}{l}\text { Disciplinas da área de Ciências nas hipóteses de } \\
\text { organização curricular conforme o CFE }\end{array}$} \\
\hline \multicolumn{2}{|c|}{ Pré-jurídico } & & Clássico & & $1^{\text {a }}$ hip. & $2^{\mathrm{a}}$ hip. & $3^{\text {a hip. }}$ & $4^{\mathrm{a}}$ hip. \\
\hline $1^{\mathrm{a}}$ & Biologia Geral & $1^{\mathrm{a}}$ & - & $1^{\mathrm{a}}$ & $\begin{array}{l}\text { Fís. } \\
\text { Quí. } \\
\text { Bio. }\end{array}$ & $\begin{array}{l}\text { Ciências } \\
\text { Físicas e } \\
\text { Biológicas. }\end{array}$ & - & $\begin{array}{l}\text { Ciências } \\
\text { Físicas e } \\
\text { Biológicas. }\end{array}$ \\
\hline $2^{\mathrm{a}}$ & - & $2^{a}$ & $\begin{array}{l}\text { Física e } \\
\text { Química }\end{array}$ & $2^{a}$ & $\begin{array}{l}\text { Fís. } \\
\text { Qui. } \\
\text { Bio. }\end{array}$ & $\begin{array}{l}\text { Ciências } \\
\text { Físicas e } \\
\text { Biológicas. }\end{array}$ & $\begin{array}{l}\text { Ciências Físicas } \\
\text { e Biológicas }\end{array}$ & $\begin{array}{l}\text { Ciências } \\
\text { Físicas e } \\
\text { Biológicas. }\end{array}$ \\
\hline & & $3^{a}$ & $\begin{array}{c}\text { Física, } \\
\text { Química } \\
\text { e Biologia } \\
\text { (depois Hist. } \\
\text { Natural) }\end{array}$ & $3^{a}$ & \multicolumn{4}{|c|}{$\begin{array}{l}\text { Não sugere disciplinas da área de ciências. } \\
\text { Livre escolha pela escola }\end{array}$} \\
\hline \multicolumn{2}{|c|}{ Pré-médico } & \multicolumn{2}{|c|}{ Científico } & \multirow{7}{*}{\multicolumn{5}{|c|}{$\begin{array}{c}\text { Obs.: Na Portaria } n^{0} 05 / 1946 \text { traz Biologia; já na Portaria nº } \\
966 / 1951 \text { esta aparece como História Natural, como era antes, } \\
\text { nos termos da Reforma de } 1931 \text {. }\end{array}$}} \\
\hline $1^{\mathrm{a}}$ & $\begin{array}{c}\text { Física, Química } \\
\text { e } \\
\text { Hist. Natural }\end{array}$ & $1^{\mathrm{a}}$ & $\begin{array}{l}\text { Física e } \\
\text { Química }\end{array}$ & & & & & \\
\hline $2^{\mathrm{a}}$ & $\begin{array}{c}\text { Física, Química } \\
e \\
\text { Hist. Natural }\end{array}$ & $2^{\mathrm{a}}$ & $\begin{array}{c}\text { Física, } \\
\text { Química } \\
\text { e Biologia } \\
\text { (depois Hist. } \\
\text { Natural) }\end{array}$ & & & & & \\
\hline & & $3^{a}$ & $\begin{array}{c}\text { Física, } \\
\text { Química } \\
\text { e Biologia } \\
\text { (depois Hist. } \\
\text { Natural) }\end{array}$ & & & & & \\
\hline \multicolumn{2}{|c|}{ Pré-politécnico } & & & & & & & \\
\hline $1^{\mathrm{a}}$ & $\begin{array}{c}\text { Física, Química } \\
\text { e } \\
\text { Hist. Natural }\end{array}$ & & & & & & & \\
\hline $2^{\mathrm{a}}$ & $\begin{array}{c}\text { Física, Química } \\
e \\
\text { Hist. Natural }\end{array}$ & & & & & & & \\
\hline
\end{tabular}

Fonte: BRASIL (1931; 1946a; 1951b; 1962a) 